\title{
Possibilities of Slovak municipalities to participate in regional development in context of globalization
}

\author{
Katarína Liptáková ${ }^{1}$, Zuzana Rigováa ${ }^{*}$ \\ ${ }^{1}$ Matej Bel University in Banská Bystrica, Faculty of Political Science and International Relations, \\ Department of Political Science, Kuzmányho 1, 97401 Banská Bystrica, Slovakia \\ ${ }^{2}$ Matej Bel University in Banská Bystrica, Faculty of Economics, Department of Quantitative \\ Methods and Information Systems, Tajovského 10, 97590 Banská Bystrica, Slovakia
}

\begin{abstract}
Nowadays, globalization affects almost all aspects of social life. It is sensible to respond flexibly to these trends and to be prepared for their benefits or potential risks. The local self-government represented by municipalities has an increasingly important role in the economic development of individual regions of Slovakia. Are municipalities prepared for the process of globalization and its impacts? Do they have tools in their hands to respond to its trends? One of the most important tasks of the municipality is to serve as an activator of regional, social and economic development and to influence the conditions for entrepreneurship by attracting potential investors to start business activities in the municipality territories. The new entrepreneurial activities and investments are a potential source of new job opportunities resulting in increased living standards of the local residents. This paper deals with indicators that express the financial capacity of the municipality and thus the ability of the municipality to participate in the process of development of a particular region. The analysis evaluates data obtained from financial statements of Slovak municipalities for year 2017. Its results show that the available financial resources of municipalities are limited and therefore the municipalities are unable to support regional development from their own financial sources.
\end{abstract}

\section{Introduction}

Globalization is about the transmission of persons, processes and products from one part of the world to another. This is a process through which material and social phenomena generated in one part of the world become part of the lives of people in other parts of the globe [1].

The effects of the globalization are manifested not only at the national level, but also at the level of mesoregions or micro-regions, so the importance of territorial units increase. This stems from the fact that local and regional development responsibilities and competencies are delegated to the regional institutions. The regional development is not the

\footnotetext{
*Corresponding author: zuzana.rigova@umb.sk
} 
government's question more and it is the responsibility of lower territorial unit. To know to the core of regional development can help explain many economic processes. It can help to forecast economic progress, helps to find possibilities how to influence different economic processes and how to deal with them. Tax policy is an important tool that the municipality can use for its further development and can be also apply for regional development of whole territory.

Municipality has a natural obligation to ensure conditions to meet the needs of the inhabitants, but also the right to regulate the development of the territory. Although, the role of local government is not to directly generate economic development, it is strongly responsible for creating suitable conditions for investments, for business activities. Municipality is an important integrating factor for effective development of the territory. It has knowledge about local needs as well as it provides many services with a direct effect on local development such as infrastructure, education, spatial planning, security, children and seniors care and etc.

The assessment of the effects of globalization is also not easy at country level, since introduced indices (e.g. KOF Index of globalization) have their shortcomings and weaknesses. Pim Martens et al. [2] consider the objective assessment of the causes, contents and consequences of globalization as a key issue for contemporary research. Their paper deal with the limitations of existing globalization indices

The indices commonly used at the country level are not suitable for evaluating globalization impacts at the micro-regional level, not only because of the data required. How can we assess the readiness of municipalities for the effects and challenges of globalization? Which existing data express the ability and readiness of the municipality to actively participate in the process of regional development? Financial aspect is not the most important determinant. The fact, that the municipality has financial resources does not guarantee that responsible authorities of municipality will use them appropriately and effectively to support the development of the administered area. Human resources are an important prerequisite to successfully cope with both the positive and negative consequences of globalization. Free financial resources are of course the basic prerequisite for the development activities of municipality.

Several authors have dealt with the determinants of regional development, their evaluation and the position of local self-government in this process. Žárska and Ferčíková [3] study the parameters of sustainable development of the regions that increase their competitiveness and define the basis on which the position of the municipalities for development processes can be evaluated. The authors Kološta et al. [4] analyse disparities of the Slovak regions through two indicators of financial autonomy and their relation to GDP per capita. Šebestová et al. [5] develop and test a new methodology of financial evaluation of municipalities based on three groups of indicators of budgetary management, municipality's indebtedness and liquidity of the municipality.

In our paper we analyse municipalities in Slovakia with respect to indicators that express how the municipality manages its financial resources and if it is able to create space to support development activities. We evaluate municipal data not only from the perspective of eight Slovak regions (NUTS 3 classification), but also in the term of size groups of municipalities, because we want to see how individual size groups of municipalities can contribute to the development activities of respective region. Our analysis is based on available quantitative data on municipalities from 2017 year. 


\section{Regional development of municipalities in the context of globalization}

Jens Bartelson [6] analyses in more detail the concept of globalization since it has undergone significant changes over the last ten years. He considers globalization to be a process of interaction and transfer between existing units, exchange across existing unit boundaries as well as between units and a system, but with an assumption that this system and units remain the same throughout the whole globalization process.

Theories of globalization tend to accentuation importance the role of regions in global economic restructuring. Globalization have reduced spatial barriers and asymmetry in development, and poor regions and rural areas may seize the new opportunities to develop their economies [7]. The globalization influence regional development of each country certainly. Competitiveness is a driver of regional development, which depends on elements of territorial capital (a set of tangible and intangible, public and private resources), but also on territorial complexity (from territorial capital, but also from other factors as how regions innovate, what is the potential of urban growth and the structural dynamics of cities) [8]. In the midst of globalization trends and European integration, local government is developing in a similar direction. Public administration emphasizes the principles of democratization, denationalization, decentralization, subsidiarity, but also the principles of "best practice", including the adoption of international experience and binding documents such as the "European Charter of Local Authorities". [9]. Globalization has a great impact on all aspects of the social life of Slovak municipalities, it can have not only positive but also a very negative impact on them. In recent years, machines have become able to replace medium-skilled workers who perform repetitive and routine tasks. This will lead to a gradual decline in demand for workers who perform basic tasks and earn low and average wages [10]. Some jobs will disappear; production will be limited what can be resulted in unemployment. This may have a negative impact on the development of whole regions. For this reason, responsible bodies should do something in advance to be able to use globalization impacts to their advantage.

Local self-government is according Asbjørn Røiseland [11] a prerequisite for local democracy. The municipality is generally the lowest administrative unit with the status of self-government, which is subordinate to national, regional and European legislation. The European Charter of Local Self-Government regulates, that local communities must be funded by state in such a way that they are able to effectively meet the public needs of the local population and increase the welfare of the society as a whole. It has a significant impact on local development.

Local self-government contributes to the economy of the municipality through decisionmaking, management, coordination, as well as economic and investment activities. Legislative framework is given by laws, which define its origin and status, structure, relations between the state and local self-government, functions, tasks, competencies and regulates economic conditions. Economic conditions considerably restrict local government expenditure. Local governments want to minimize spending or investing money through incentives for economic development.

It is necessary for municipalities to be actively involved in economic development. Municipality can enter to economic development of region in various ways, e.g. by utilization of municipal property, financial resources at its disposal and by managing the activities of all economic subjects [12]. The level of financial capacity of local budgets plays an important role in sustainable socio-economic development of the region. The good financial condition of the municipalities is reflected in the successful development of the regions. The financial credibility of a local budget determines the competitiveness of a region and ensures the effective implementation of its economic objectives as well as the feasibility of the financial security of regional development [13]. 
In the Slovak Republic, a municipality is an independent territorial and administrative unit. It is defined as a legal entity managing its own assets and financial resources (own revenues as well as state subsidies) under the conditions laid down by the law Act no. 369/1990 Coll. [14]. Authorities of municipalities are responsible for the providing and financing of original and transferred competencies in Slovakia. Original competencies are financed from internal and transferred competencies (e.g. primary education) from external sources, through purpose subsidies, which reduce the degree of financial autonomy of municipalities. The financial condition of the municipality is very important attribute, because its indicators express the state of functioning of the municipality and the efficiency of its financial management, as well as its ability to support development activities in the administered territory from its own financial resources

The main income of municipalities are shared taxes, but also local taxes and fees, property income, state subsidies. Local taxes according Act No. 582/2004 Coll. [15] in Slovakia include: real estate tax, dog tax, tax on the use of public areas, accommodation tax, tax on sales vending machines, tax on non-winning gaming machines, tax on the entry and staying of motor vehicles in historical parts of towns, nuclear facility tax and local development fee. Municipalities impose local fee for municipal waste and minor construction waste too. With the exception of the last mentioned fee, they are all optional. It is up to the municipality, whether it introduces the local tax or not.

The basis of the financial analysis of municipality is the selection of indicators that can be used for analysing. In the following analysis, we evaluate the assumptions of Slovak municipalities for the development process through the several indicators of financial capacity and autonomy: financial and tax strengths, rates of self-financing and tax autonomy.

\section{Data and methodology}

In Slovakia, there are 2927 municipalities with a city, village or military district status, with the various number of the inhabitants and belonging to one of the eight Slovak regions. The analysis includes only quantitative data, especially financial data on the performance of municipalities, since they are publicly available or provided on request. Some of the data was provided by Slovak DataCentrum (mainly financial indicators of municipality incomes and expenses in year 2017, (all together) in the structure of size categories by municipality population and categorized according to the functional and economic classification) and by Statistical Office of Slovak Republic (size groups of municipalities according the number of inhabitants in year 2017).

Finally, 2885 municipalities (cities and villages) are incorporated into our analysis (we excluded some of them due to missing data). Regarding to the structure of data from DataCentrum and our intention we grouped municipalities by the total number of inhabitants in a municipality and by the region. In Slovakia we have eight regions (in our analysis we will use abbreviation of their names: Bratislava Region - BA, Trnava Region TT, Trenčín Region - TN, Nitra Region - NR, Žilina Region - ZA, Banská Bystrica Region - BB, Prešov Region - PO and Košice Region - KE). Based on the size of population, we divided them into the following size groups: from 0 to 99,100 to 499,500 to 999,1000 to 2999,3000 to 4999,5000 to 9999,10000 to 19999,20000 to 49999 , 50000 to 99999 and the last one over 100000 inhabitants. Further in this paper, we mention only the upper limit of the intervals, i.e. $-99,-499,-999,-2999$ etc. Combining the region and size, we obtain 71 groups of the municipalities, hereinafter referred to as region-size groups. It means that each region-size group will be a proxy municipality that represents a certain number of Slovak municipalities belonging to the particular Slovak 
region and size group. Due to this fact, all used source data is adjusted in the analysis.

Table 1 shows the number of the municipalities included in the region-size groups.

Table 1. Frequency of municipalities in region-size groups

\begin{tabular}{|c|c|c|c|c|c|c|c|c|c|c|c|}
\hline 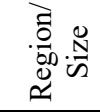 & aे & ஓे & के & & ஓे & ڤे & $\frac{\curvearrowright}{\circ}$ & ஓे & बे & $\begin{array}{l}8 \\
8 \\
8\end{array}$ & $\frac{n}{\frac{\pi}{0}}$ \\
\hline BA & 1 & 5 & 12 & 38 & 6 & 5 & 3 & 1 & & 1 & 72 \\
\hline TT & & 45 & 73 & 103 & 14 & 6 & 5 & 4 & 1 & & 251 \\
\hline $\mathrm{TN}$ & 5 & 76 & 84 & 81 & 15 & 4 & 5 & 5 & 1 & & 276 \\
\hline NT & 1 & 94 & 99 & 129 & 13 & 7 & 4 & 5 & 1 & & 353 \\
\hline $\mathrm{ZA}$ & 10 & 83 & 73 & 108 & 20 & 13 & 3 & 3 & 2 & & 315 \\
\hline $\mathrm{BB}$ & 27 & 246 & 130 & 84 & 7 & 10 & 6 & 4 & 1 & & 515 \\
\hline $\mathrm{PO}$ & 75 & 285 & 156 & 114 & 14 & 7 & 6 & 4 & 2 & & 663 \\
\hline $\mathrm{KE}$ & 6 & 170 & 138 & 96 & 15 & 9 & 2 & 3 & & 1 & 440 \\
\hline Totals & 125 & 1004 & 765 & 753 & 104 & 61 & 34 & 29 & 8 & 2 & 2885 \\
\hline
\end{tabular}

Source: the authors based on data from DataCentrum.

In terms of the size groups of municipalities, up to $87.4 \%$ of municipalities belong to the small size $-499,-999$ and to $-2999(34.8 \%, 26.5 \%$ and $26.1 \%$, respectively). In region point of view, the highest number of municipalities is located in Prešov region, followed by Banská Bystrica and Košice regions $(22.9 \%, 17,9 \%$ and $15.3 \%$, respectively as mentioned) and the lowest number is in Bratislava, Trnava and Trenčín regions $(2.5 \%, 8,7 \%$ and $9.6 \%$, respectively).

We start with indicators of tax and financial strength of the municipalities per capita, since they inform us how much money the municipality gets per capita and can use for financing its original competencies. Tax strength of the municipality measures the tax yield of the municipality and it reflects the proportion of local and shared taxes per capita. The financial strength is extended by the volume of subsidies (domestic grants and transfers) compared to the tax strength, so also expresses the degree of dependence on the state budget and represents the income stability of the municipality.

We also present values of the two ratio indicators, self-financing rate (SFRate) that quantify the space for possible development activities of the municipality from own financial sources and rate of tax autonomy (RateofTA) that quantify the ability of the municipality to ensure income from own sources - local taxes.

Self-financing rate informs us whether the municipality is able to cover current expenses from its own incomes and is calculating as a ratio of own (current) revenues ${ }^{\dagger}$ to the current expenditure. If its value is less than 1, municipality needs external financial help/resources for development projects and contrary, the value greater than 1 expresses the ability of municipality to invest using own resources. The rate of tax autonomy is calculated as the ratio of local taxes on total revenues and expresses tax autonomy of the municipality.

All considered indicators are calculated and adjusted to the population size and the number of municipalities in individual region-size groups.

\section{Results}

The values of tax and financial strength per capita are shown in Fig. 1. and Fig. 2. for regions and size groups, respectively.

Naturally, the per capita financial strength values are higher than the tax strength values. The difference between these two indicators reflects the proportion of state subsidies in

\footnotetext{
$\dagger$ Own revenues=local taxes+shared taxes+other tax revenues+current non-tax revenues
} 
financial strength per capita. From the perspective of regions, we can see that the lowest value of tax strength was reached in the Košice region (321,3€ per capita), the highest ones in the Bratislava region (432.9 €). This indicator is very similar in case of Košice, Prešov and Banská Bystrica regions, values fluctuate around $330 €$ per capita, towards the west part of Slovakia are growing.

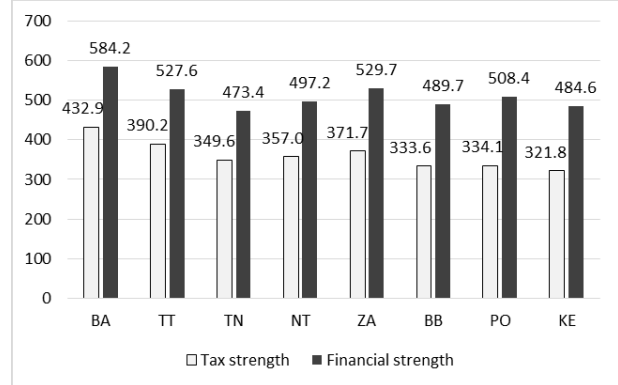

Fig. 1. Indicators of financial capacity per capita (in $€$ ) by regions

Source: the authors based on data from DataCentrum and Statistical Office of Slovak Republic

Regarding the financial strength, values varied from $473.4 €$ per capita, the lowest value in Trenčín region to $584.2 €$ per capita, again, the highest value exhibits Bratislava region. In terms of the size groups, the values of both indicators increase as size groups increase, with the exception of the size groups -19 999 and -49 999, where values are slightly smaller than in the size group -9999 . The highest values are reported by municipalities of the size group 100000 , the lowest ones are in size group -99 .

The values of considered rates are shown in Fig. 3. and Fig. 4. by regions and size groups, respectively.

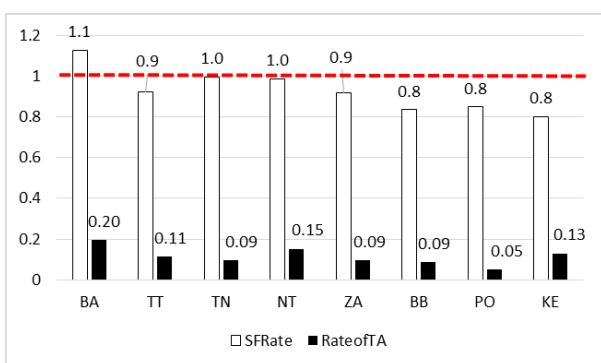

Fig. 3. Indicators of financial autonomy by regions

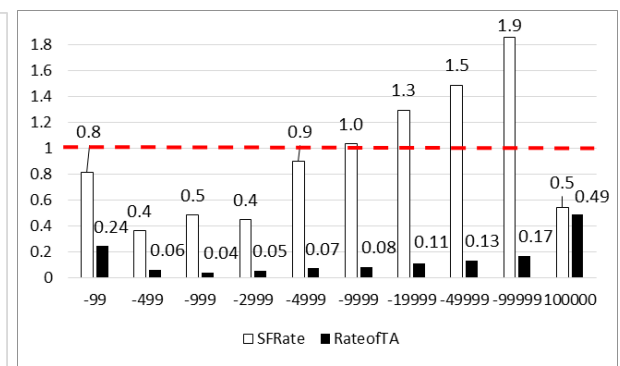

Fig. 4. Indicators of financial autonomy by size group

Source: the authors based on data from DataCentrum and Statistical Office of Slovak Republic

In Fig. 3. we observe that both rates, except for SFRate in Bratislava region are below the value 1 (SFRate of Trenčín and Nitra regions are 0.99). Three lowest values of SFRates were achieved again in Banská Bystrica, Prešov and Košice regions, Trnava region disrupt the increasing trend of SFRate from eastern to western part of Slovakia. Naturally, the lower values are reported in case of RateofTA. The lowest value was achieved in Prešov region, where local taxes account for only $5 \%$ and the highest one in Bratislava region, with the proportion of local taxes about $20 \%$.

In term of size groups (Fig. 4.) we observed that only SFRate in case of size municipalities from -9999 to -99999 reports the values greater than 1. Surprisingly, the increasing trend of SFRate with increasing size group is interrupted by size group 100 000, 
that reports value of SFRate below 0.5. However, this size group achieves the highest value of RateofTA (0.49). Naturally, the lower values are reported in case of RateofTA, relatively the lowest one is achieved in size group -999 (the proportion of local taxes on total revenues is only 4\%) and relatively the highest value in size group 100000 (0.49). Interesting situation is in case of size group -99, where the values of both rates are higher than the values in greater size groups $-499,-999$ and even in -2999.

\section{Conclusion}

The analysis focused on several indicators in order to identify the ability of Slovak municipalities to actively participate in the development activities of managed territory. Qualified and educated management focused on further development of the municipality is a crucial factor, although, available financial resources are a prerequisite. Based on the financial data for year 2017, we evaluated several financial indicators of municipal management. The results show that the available financial resources of municipalities are limited and therefore the municipalities are unable to support regional development from their own financial sources.

It seems that self-governing regions located in the western part of Slovakia with the largest share of foreign investment, have a higher tax and financial strength compared to the rest of the country. These strengths observed in the eastern regions are slightly declining. In terms of size groups, both analysed indicators grow with the increasing size category of the municipality (except the size group -49 999). The development of the financial strength follows the development of the tax strength, only subsidies differentiate this trend. In local conditions the subsidies serve mainly to offset fiscal imbalances between municipalities. They are purpose-assigned and they have a minimal share on development.

The results of the self-financing rate analysis showed that the value of this indicator is higher than 1 only in the Bratislava region, i.e. that there is only a budget surplus. In Trnava and Nitra regions the budget is almost balanced and in other regions it is deficit. The surplus was achieved only in the budget of the Bratislava region and could be used to finance development activities. In regards to the tax autonomy, we can say that the share of local taxes on total revenues in Slovakia is insignificant (its value is 0.2 at maximum). In case of Prešov region it is only 0.05 , which again indicates significant regional disparities. It could be a topic for further expert discussion focused on the importance of the local taxes in Slovak conditions.

In term of individual size groups of municipalities, municipalities with less than 5000 inhabitants do not have a budget surplus and do not generate financial resources for development according our analysis (SFRate is less than 1). In the case of larger size groups (with the exception of 100000 ), they generate a budget surplus that can be used for development activities. The highest values of tax autonomy rate exhibit municipalities in the highest size group 100000 (local taxes creates 49\% of total revenues), but surprisingly, the second highest value was achieved by municipalities in the smallest size group -99 (with the proportion of local taxes $24 \%$ ).

In conclusion, the available financial data does not provide sufficient grounds to determine the readiness of this territory to respond to the varying effects of globalization. The findings of this paper are limited to the availability of qualitative data such as readiness and competence of the human capital responsible for the administration in the local municipalities. The outcome of this analysis suggests the necessity to further research the underlying topic.

The paper is processed as the output of the research project "The impact of local taxes on the fulfillment of local government tasks in economically developed and lagging regions in the context of industry 4.0". The project is registered by the Scientific Grant Agency of the Ministry of Education, 
Science, Research and Sport of the Slovak Republic under registration number 1/0151/18. It is implemented in the years 2018-2021 at the Matej Bel University in Banská Bystrica.

\section{References}

1. I. Prilleltensky. The what, why, who, and how of globalization: What is psychology to do? In Journal of Social Issues. 68, 3, 612-629 (2012)

2. P. Martens, M. Caselli, P. De Lombaerde et al. New directions in globalization indices. In Globalizations. 12, 2, 217-228 (2014)

3. E. Žárska, V. Ferčíková. Municipal creditworthiness as a determinant of development. In 17th International Colloquium on Regional Sciences. 477-484(2014)

4. S. Kološta, P. Bolcárová, F. Flaška. Financial autonomy of municipalities in relation to economic performance in regions of the Slovak republic. In Political Sciences, Law, Finance, Economics and Tourism, II, 279-286 (2014)

5. J. Šebestová, I. Majerová, I. Szarowska. Indicators for assessing the financial condition and municipality management. In Administratie si Management Public. 31, 97-110 (2018)

6. Jens Bartelson. Three concepts of globalization. In International Sociology. 15, 2, 180 196 (2000)

7. Y.D. Wei, J. Lin, L. Zhang. E-Commerce, taobao villages and regional development in China. In GEOGRAPHICAL REVIEW. 1-26. (2019). (to be published). Available at https://www.researchgate.net/publication/333787791_E-

commerce_taobao_villages_and_regional_development_in_China

8. R. Cabello. Regional development theories and formalised economic approaches: an evolving relationship. In ITALIAN ECONOMIC JOURNAL, 5, 1, 1-16 (2019)

9. E. Bakoš, J. Soukopová, J. Šelešovský. The historical roots of local self-government in Czech and Slovak republics. In Lex Localis. 13, 1, 1-19 (2015)

10. I. Visco. Stability and growth in a global economy. In PSL QUARTERLY REVIEW. 72, 289, 75-84 (2019)

11. A. Røiseland. Local self-government or local co-governance? In Lex Localis. 8, 2, 133 145 (2010)

12. A. Belajová, E. Balážová. Ekonomika a manažment územných samospráv. Nitra: Slovenská polnohospodárska univerzita. (2004).

13. O. Liuta, N. Pihul, T. Kubakh. Financial capacity of local budget as a basis for sustainable functioning of a territory. In Economic Annals, XXI, 1-2(1), 78-81 (2015). Available at http://soskin.info/userfiles/file/2015/1-2_1_2015/Liuta_Pihul_Kubakh.pdf

14. Act no. 369/1990 Coll. on Municipalities (in Slovak) as amended. Retrieved 2017-0823 from http://www.zakonypreludi.sk/zz/1990-369

15. Act No. 582/2004 Coll. on Local Taxes and Local Fee for Municipal Waste and Minor Construction Waste as amended 